\title{
FACTORS ASSOCIATED WITH STUNTING AMONG CHILDREN 1 - 3 YEARS OF AGE IN BATU CITY, EAST JAVA
}

\author{
Juin Hadisuyitno, B. Doddy Riyadi \\ Diploma III Program of Nutrition, Department of Nutrition, \\ School of Health Polytechnics, Ministry of Health, Malang
}

\begin{abstract}
Background: Stunting status among children indicate a chronic malnutrition that illustrate the inhibition of growth. Stunted in children can reduce the cognitive intelligence of children facing a greater likelihood of growing into adults who are less educated, poor, less healthy and more vulnerable to non-communicable diseases. This study aimed to determine the factors associated with stunting among children around 1 to 3 years of age in Batu City, East Java.

Subject and Method: This was a case-control study conducted in Batu City, East Java. A total of 90 children around 1 to 3 years of age was selected for this study, consisting of 45 stunted and 45 non-stunted children. The dependent variable was stunting. The independent variables were low birth weight, exclusive breastfeeding, complementary feeding, history of illness, completeness of immunization, duration of breastfeeding, and length of birth. The data were collected by questionnaire and analyzed by Chi-square.

Result: The risk of stunting increased by low birth weight $(\mathrm{OR}=1.75 ; 95 \% \mathrm{CI}=0.39$ to $7.81 ; \mathrm{p}=0.714)$, non-exclusive breastfeeding $(\mathrm{OR}=1.11 ; 95 \% \mathrm{CI}=0.46$ to $2.68 ; \mathrm{p}=$ 0.822), inappropriate complementary feeding ( $\mathrm{OR}=2.07 ; 95 \% \mathrm{CI}=0.89$ to $4.83 ; \mathrm{p}=$ o.09), history of illness ( $\mathrm{OR}=2.00 ; 95 \% \mathrm{CI}=0.61$ to $6.52 ; \mathrm{p}=0.245)$, uncompleted immunization $(\mathrm{OR}=0.39 ; 95 \% \mathrm{CI}=0.12$ to $1.23 ; \mathrm{p}=0.980)$, duration of breastfeeding $<1$ year $(\mathrm{OR}=0.41 ; 95 \% \mathrm{CI}=0.16$ to $1.06 ; \mathrm{p}=0.630)$, but they were not statistically significant. The risk of stunting increased by length birth $<48 \mathrm{~cm}(\mathrm{OR}=0.22 ; 95 \% \mathrm{CI}=0.07$ to $0.72 ; p=0.008$ ), and it was not statistically significant.
\end{abstract}

Conclusion: Length of birth $<48 \mathrm{~cm}$ increases the risk of stunting among children aged 1-3 years.

Keywords: stunting, low birth weight, length of birth

Correspondence:

Juin Hadisuyitno. Diploma III Program of Nutrition, Department of Nutrition, School of Health Polytechnics, Ministry of Health Malang, East Java. Email: juinhadi@gmail.com. Mobile: 081555653485 .

The $6^{\text {th }}$ International Conference on Public Health

Best Western Premier Hotel, Solo, Indonesia, October 23-24, 2019 | 37 https://doi.org/10.26911/the6thicph.01.14 